\title{
Ulasan Peraturan \\ Permen KP No.21/Permen-KP/2015 tentang Kemitraan Pengelolaan Kawasan Konservasi Perairan
}

Margaretha Quina

Pada 26 Juni 2015, Peraturan Menteri Kelautan dan Perikanan RI No. 21 PermenKP/2015 ("Permen KP No. 21/2015") tentang Kemitraan Pengelolaan Kawasan Konservasi Perairan diundangkan, delapan tahun setelah dimandatkan. Peraturan ini merupakan peraturan pelaksana dari ketentuan Pasal 18 ayat (2) Peraturan Pemerintah No. 60 Tahun 2007 tentang Konservasi Sumber Daya Ikan. Pasal 18 ayat (1) menetapkan bahwa dalam pengelolaan kawasan konservasi perairan, Pemerintah atau Pemerintah Daerah dapat "melibatkan" masyarakat. Pelibatan masyarakat ini dilakukan melalui kemitraan antara unit organisasi pengelola dengan kelompok masyarakat dan/atau masyarakat adat, lembaga swadaya masyarakat, korporasi, lembaga penelitian, maupun perguruan tinggi. ${ }^{1}$

Munculnya peraturan ini telah membawa ragam reaksi dan ekspektasi dari berbagai kalangan, terutama dalam kaitannya dengan perwujudan konservasi yang merangkul, bukan menyingkirkan masyarakat. Tulisan ini bermaksud menginformasikan materi muatan Permen 21/2015, dengan potensi maupun kekurangannya, agar masyarakat dapat semaksimal mungkin mengawasi dan mengambil bagian dalam pelibatan masyarakat dengan kemitran KKP. Tulisan ini tidak dimaksudkan untuk secara mendalam membedah pemaknaan kemitraan dalam hubungannya dengan teori pelibatan masyarakat.

\section{Relevansi Aktual: Konservasi yang Merangkul, Bukan Menyingkirkan}

Dalam 8 (delapan) tahun interval tersebut, berbagai tekanan antara nelayan tradisional, pelaku bisnis, maupun masyarakat adat dengan kawasan konservasi telah mengemuka. Terdapat beberapa permasalahan aktual terkait dengan pelibatan

1 Indonesia (a), Peraturan Pemerintah tentang Konservasi Sumber Daya Ikan, PP No. 60 Tahun 2007, LN No. 134 Tahun 2007, TLN No. 4779. Lih: Pasal 18 ayat (1) dan (2). 
masyarakat ini yang seharusnya dapat disikapi lebih baik dengan munculnya Permen KP 21/2015 ini.

Pertama, ketidakpahaman nelayan tradisional mengenai hak dan kewajiban dalam kawasan konservasi serta tata batas kawasan konservasi laut, yang kerap berujung pada ancaman pidana terhadap nelayan tradisional di kawasan konservasi. Tahun 2015 menyaksikan, di antaranya, 4 nelayan tradisional yang mengambil terumbu karang ditangkap di kawasan konservasi perairan Pulau Menjangan $^{2}$ dan 3 nelayan tradisional di perairan Teluk Kelor Taman Nasional Bali Barat (TNBB). ${ }^{3}$ Pemberitaan di media bersimpati atas kasus-kasus ini, di mana beberapa nelayan, baik karena ketidaktahuan atau pilihan yang dibuat karena “keterpaksaan" struktural, berujung di bui. Dalam JHLI Volume 2/1, salah satu tulisan membahas tekanan konservasi ini, yang sayangnya, karena kemudahan pembuktian dan lain-lain hal, cenderung berat kepada nelayan tradisional dibandingkan perusahaan besar.

Kedua, praktek penangkapan ikan masyarakat lokal yang kurang ramah lingkungan. Larangan praktek penggunaan bom ikan, bius dan pukat harimau terkadang disikapi pengguna alat-alat tersebut dengan resistensi. Mengingat dampak positif penggunaan alat-alat ramah lingkungan akan tampak dalam jangka waktu menegah hingga panjang, misalnya dengan pulihnya hasil tangkapan laut yang sensitif, tidak jarang resistensi ini disebabkan kurangnya pengetahuan atau keyakinan pengguna alat akan kemanfaatan penggunaan alat-alat tersebut. Contohnya, kemitraan yang terbangun antara masyarakat resisten dan Polres Pangkajene baru tumbuh setelah pulihnya populasi cumi-cumi dan ikan tongkol di perairan tersebut, sebagai hasil penegakan hukum yang konsisten atas larangan penggunaan alat-alat tidak ramah lingkungan. ${ }^{4}$ Dengan beragam contoh baik yang telah terbangun, resistensi ini dapat ditanggulangi dengan pembinaan masyarakat, mengurangi porsi pemidanaan terhadap kasus-kasus yang sifatnya struktural dan kuat dipengaruhi faktor edukasi, serta memanfaatkan kearifan lokal untuk menjembatani larangan-larangan dalam konservasi.

2 Tribun Bali, 4 Nelayan Tradisional Ditangkap di Perairan Pulau Menjangan, 18 Agustus 2015, sumber: http:// bali.tribunnews.com/2015/08/18/4-nelayan-tradisonal-ditangkap-diperairan-pulau-menjangan?page $=2$ diakses pada 20 Desember 2015.

3 Tribun Bali, Menangkap Ikan di Daerah Konservasi, Tiga Nelayan Tradisional Ditangkap, 25 Maret 2015, sumber: http://bali.tribunnews.com/2015/03/25/menangkap-ikan-di-daerahkonservasi-tiga-nelayan-tradisional-ditangkap diakses pada 20 Desember 2015.

4 Kriminalitas.com, Cerita dari Pulau, Menangkap Nelayan Pengguna Jaring yang Merusak Terumbu Karang, 3 Desember 2015, sumber: http://kriminalitas.com/cerita-dari-pulaumenangkap-nelayan-pengguna-jaring-yang-merusak-terumbu-karang/ diakses pada 20 Desember 2015. 
Ketiga, lemahnya pengawasan pemerintah terhadap kegiatan di pesisir dan/ atau laut yang berdampak langsung pada kawasan konservasi. Dengan total wilayah konservasi laut di Indonesia yang mencapai 17,2 juta $\mathrm{Ha},{ }^{5}$ dibutuhkan sumber daya yang luar biasa besar untuk memantau dan menindak semua pelanggaran hukum di wilayah konservasi laut atau di wilayah penyangganya. Sayangnya, aparat berwenang lebih banyak berfokus pada penindakan pelanggaran yang dilakukan nelayan tradisional/masyarakat lokal dalam skala kecil dan individual dibandingkan pelanggaran atau kejahatan oleh kapal penangkap ikan skala menengah/besar, penambangan pasir ilegal, dan pengambilan terumbu karang dan/atau flora/fauna dilindungiyang terorganisasi. Padahal, beberapa pembelajaran konkritmenunjukkan pengawasan oleh masyarakat dapat membantu pemerintah melakukan fungsi pengawasan dan penindakannya. Misalnya Kelompok Masyarakat Pengawas di KKP Raja Ampat, ${ }^{6}$ yang diedukasi dan konsisten melakukan pengawasan, menegur jika melakukan pelanggaran, dan melakukan pendekatan dan sosialisasi kepada masyarakat yang melakukan pelanggaran. ${ }^{7}$ Contoh baik lain di tahun 2015 datang dari KKP Nusa Penida, di mana informasi warga setempat membantu UPT KKP Nusa Penida menangkap kapal penangkap lobster di kawasan konservasi. ${ }^{8}$

\section{Menelaah Materi Muatan Permen KP 21/2015: Menjawab Permasalahan?}

Dari sisi fungsi regulasinya, Permen KP 21/2015 memiliki keunikan karena memformalisasi praktek-praktek kemitraan Pemerintah dengan masyarakat yang telah tumbuh berdasarkan inisiatif, dan di saat yang bersamaan mencoba memberikan insentif agar praktek-praktek kemitraan baru dapat muncul. Materi muatan Permen KP 21/2015 terdiri atas 6 Bab, yang terdiri dari (i) ketentuan umum; (ii) persyaratan kemitraan; (iii) mekanisme kemitraan; (iv) pembinaan, monitoring dan evaluasi; (v) ketentuan lain-lain; dan (vi) ketentuan penutup.

5 Direktorat Jenderal Kelautan, Pesisir dan Pulau-pulau Kecil Kementerian Kelautan dan Perikanan, Penambahan Luas Kawasan Konservasi Lampaui Target, 28 Oktober 2015, sumber: http://www.djkp3k.kkp.go.id/index.php/arsip/c/438/?category_id=20 diakses pada 20 Desember 2015.

6 Antara Sulsel, Belajar Konservasi dari Raja Ampat, 28 April 2015, sumber: http://www. antarasulsel.com/berita/64462/belajar-konservasi-dari-raja-ampat diakses pada 20 Desember 2015.

$7 \quad$ Ibid.

8 Berita Satu, Masyarakat Ikut Aktif Awasi Kawasan Konservasi Nusa Penida, 28 Juni 2015, sumber:http://www.beritasatu.com/nasional/286446-masyarakat-ikut-aktif-awasikawasan-konservasi-nusa-penida.html diakses pada 20 Desember 2015. 


\section{Memaknai Kemitraan}

Dalam KBBI, kemitraan didefinisikan sebagai "perihal hubungan (jalinan kerja sama dsb) sebagai mitra," dengan arti mitra "(1) teman; sahabat; (2) kawan kerja; pasangan kerja; rekan." Sementara, dalam Permen KP 21/2015, definisi kemitraan sendiri dituangkan dalam Pasal 1 ayat (2), konsisten dengan penjelasan Pasal 18 PP 60/2007, di mana dirumuskan beberapa karakteristik kemitraan: (1) hubungan kerja sama; (2) antara dua pihak atau lebih; (3) berdasarkan kesetaraan, keterbukaan dan saling menguntungkan. ${ }^{9}$ Namun, sekalipun definisinya kemitraan jika dilihat secara terisolasi cukup baik, memaknai kemitraan dalam Permen 21/2015 ini tidak lepas dari 2 kondisi: (1) kemitraan dilakukan berdasarkan Rencana Pengelolaan dan Zonasi Kawasan Konservasi Perairan, ${ }^{10}$ yang notabene disusun oleh Pemerintah; dan (2) kemitraan dilakukan dalam skema Program Kemitraan Kawasan Konservasi Perairan ("Program Kemitraan”), yang dapat diajukan oleh Pemerintah kepada masyarakat ataupun sebaliknya.

Artinya, jika definisi tersebut diinterpretasikan dalam konteks keseluruhan materi muatan Permen 21/2015, dapat disimpulkan satu hal: kemitraan yang diatur dalam Permen KP 21/2015 ini bersifat programatis, terencana, formal, dan berdasarkan hak dan kewajiban yang lebih rigid. Kemitraan ini hanya terbatas pada program yang telah direncanakan pemerintah, yang dalam perencanaannya sendiri kerap dikritik kurang melibatkan masyarakat, atau hanya melibatkan kelompok-kelompok yang memiliki akses / previlege lebih besar untuk mempengaruhi kebijakan. Di dalamnya, terdapat unsur birokrasi yang kental. Pemaknaan terminologi "kemitraan," yang berhubungan erat dengan mandat "melibatkan" masyarakat dalam PP 60/2007, sayangnya, tereduksi menjadi hubungan kontraktual untuk melaksanakan program pemerintah dalam Permen 21/2015 ini. Hal ini sedikit berbeda dengan inisiatifinisiatif kemitraan yang sudah berjalan saat ini, yang banyak tumbuh dari kesukarelaan masyarakat dan bersifat cair, hingga pada akhirnya beberapa diadopsi dalam program terencana oleh Pemerintah.

9 Indonesia (a), Op.Cit., Pasal 18 bagian Penjelasan.

10 Sementara itu, Program Kemitraan Kawasan Konservasi Perairan ("Program Kemitraan”) didefinisikan dengan unsur sbb: (1) rencana; (2) yang memuat kegiatan-kegiatan kemitraan; (3) sesuai dengan rencana pengelolaan dan zonasi kawasan konservasi perairan. Lih: Menteri Kelautan dan Perikanan RI, Peraturan Menteri Kelautan dan Perikanan RI tentang Kemitraan Pengelolaan Kawasan Konservasi Perairan, Permen KP No. 21/Permen-KP/2015, BN No. 952 Tahun 2015. 
Dengan perumusan yang ada sekarang, terdapat satu prasyarat yang harus disadari pemerintah agar program-program kemitraan dalam Permen 21/2015 ini benar-benar terlaksana secara bermakna: pemerintah perlu menyadari, menganalisis dan menjawab beberapa permasalahan-permasalahan di atas dalam menyusun Rencana Pengelolaan dan Zonasi Kawasan Konservasi Perairan. Dengan demikian, di sinilah masyarakat perlu untuk mencurahkan energinya untuk "melibatkan diri" sesuai dengan prosedur yang ada dalam perencanaan pengelolaan dan zonasi KKP, sebagaimana tertuang dalam Permen KP No. 30 Tahun 2010. ${ }^{11}$ Dengan kesadaran bahwa "kemitraan" yang digaunggaungkan hanya dapat berfungsi dengan baik jika RPZ KKP dirumuskan dengan baik, masyarakat memiliki dua kali kesempatan konsultasi publik untuk memastikan permasalahan-permasalahan riil dapat masuk dalam poinpoin rencana pengelolaan, sehingga nantinya masyarakat dapat mengajukan usulan kemitraan sesuai dengan permasalahan yang ada.

\section{Mengantisipasi Penyalahgunaan Pelibatan Masyarakat}

Hal lain yang perlu diantisipasi adalah oknum-oknum yang mengatas namakan masyarakat dalam implementasi program. Sebagaimana dielaborasi dalam Pasal 3, terminologi "masyarakat" dalam Permen 21/2015 ini mencakup unsur kelompok masyarakat, masyarakat adat, LSM, korporasi, lembaga penelitian dan perguruan tinggi. Salah satu fitur Permen 21/2015 yang mengakomodasi fungsi antisipasi ini adalah persyaratan-persyaratan yang dibebankan kepada berbagai unsur agar dapat terlibat dalam program kemitraan.

Dalam pasal 4, ditentukan persyaratan unsur-unsur tersebut agar dapat terlibat dalam program kemitraan. Persyaratan-persyaratan tersebut terdiri atas: (i) Persyaratan yang bersifat legal formil yang mensyaratkan kelengkapan dokumen yang dibutuhkan; (ii) Persyaratan substantif terkait kecakapan dan akuntabilitas calon mitra dan/atau program yang telah dijalankan. ${ }^{12}$ Dalam

11 Menurut Permen KP No. 30 Tahun 2010, tahapan penyusunan rencana pengelolaan kawasan konservasi perairan jangka panjang dan jangka menengah serta zonasi kawasan konservasi perairan meliputi: (1) pembentukan kelompok kerja; (2) pengumpulan data dan informasi; (3) analisis; (4) penataan zonasi kawasan konservasi perairan; (5) penyusunan rancangan rencana jangka panjang dan rencana jangka menengah; (6) konsultasi publik pertama; (7) perumusan zonasi dan rencana pengelolaan kawasan konservasi perairan; (8) konsultasi publik kedua; dan (9) perumusan dokumen final. Lih: Menteri Kelautan dan Perikanan RI, Peraturan Menteri Kelautan dan Perikanan RI tentang Rencana Pengelolaan dan Zonasi Kawasan Konservasi Perairan, Permen KP No. 30 Tahun 2010.

Menteri Kelautan dan Perikanan RI, Op. Cit., Pasal 3. 
Permen 21/2015 ini, persyaratan yang lebih mengemuka justru persyaratanpersyaratan formil, sementara kriteria kecakapan dan akuntabilitas atau kinerja riil calon mitra yang telah berkontribusi terhadap konservasi kurang diberi porsi dibandingkan dengan persyaratan formil. Untuk persyaratan formil \& substantif masing-masing unsur, dapat dilihat di tabel sbb:

\begin{tabular}{|c|c|c|c|}
\hline & Unsur & Syarat Substantif & Syarat Formil \\
\hline 1. & $\begin{array}{l}\text { Kelompok } \\
\text { masyarakat dan } \\
\text { masyarakat adat }\end{array}$ & $\begin{array}{l}\text { Tinggal di dalam atau } \\
\text { di sekitar kawasan } \\
\text { konservasi }\end{array}$ & $\begin{array}{l}\text { KTP atau surat keterangan } \\
\text { dari Kepala Desa/Lurah }\end{array}$ \\
\hline \multirow[t]{4}{*}{2.} & LSM & & \\
\hline & $\begin{array}{l}\text { a. LSM provinsi } \\
\text { atau kabupaten/ } \\
\text { kota }\end{array}$ & $\begin{array}{l}\text { Berada di sekitar } \\
\text { kawasan konservasi } \\
\text { perairan }\end{array}$ & -- \\
\hline & b. LSM nasional & $\begin{array}{l}\text { Memiliki program } \\
\text { terkait konservasi dan } \\
\text { pengelolaan sumber } \\
\text { daya ikan }\end{array}$ & $\begin{array}{ll}\text { 1. } & \text { Memiliki kesepakatan } \\
\text { bersama dengan } \\
\text { Kementerian untuk KKP } \\
\text { nasional; } \\
\text { 2. Memiliki kesepakatan } \\
\text { bersama dengan Pemda } \\
\text { Provinsi untuk KKP } \\
\text { Provinsi. } \\
\text { 3. Berbadan hukum } \\
\text { Indonesia. }\end{array}$ \\
\hline & c. LSM asing & $\begin{array}{l}\text { Memiliki program } \\
\text { terkait konservasi dan } \\
\text { pengelolaan sumber } \\
\text { daya ikan }\end{array}$ & $\begin{array}{l}\text { 1. Memiliki kesepakatan } \\
\text { bersama dengan } \\
\text { Pemerintah; } \\
\text { 2. Terdaftar di Kementerian } \\
\text { Luar Negeri }\end{array}$ \\
\hline 3. & Korporasi & $\begin{array}{l}\text { 1. Tidak sedang dalam } \\
\text { proses hukum; dan/ } \\
\text { atau } \\
\text { 2. Tidak termasuk } \\
\text { dalam daftar } \\
\text { peringkat hitam } \\
\text { program PROPER }\end{array}$ & -- \\
\hline \multirow[t]{3}{*}{4.} & Lembaga penelitian & & \\
\hline & a. Dalam negeri & -- & $\begin{array}{l}\text { Memiliki izin penelitian dan } \\
\text { pengembangan perikanan } \\
\text { dengan objek yang memiliki } \\
\text { karakteristik unik }\end{array}$ \\
\hline & b. Asing & -- & $\begin{array}{l}\text { Memiliki izin penelitian dari } \\
\text { instansi yang berwenang }\end{array}$ \\
\hline 5. & Perguruan Tinggi & & \\
\hline
\end{tabular}




\begin{tabular}{|c|c|c|}
\hline $\begin{array}{l}\text { a. Perguruan } \\
\text { tinggi nasional }\end{array}$ & $\begin{array}{l}\text { Memiliki program } \\
\text { terkait konservasi dan } \\
\text { pengelolaan sumber } \\
\text { daya ikan }\end{array}$ & $\begin{array}{l}\text { 1. Memiliki kesepakatan } \\
\text { bersama dengan } \\
\text { kementerian untuk } \\
\text { kawasan KKP nasional; } \\
\text { 2. Memiliki kesepakatan } \\
\text { bersama dengan } \\
\text { pemerintah daerah } \\
\text { provinsi untuk KKP } \\
\text { daerah provinsi; } \\
\text { 3. Perguruan tinggi negeri } \\
\text { atau berbadan hukum } \\
\text { Indonesia. }\end{array}$ \\
\hline
\end{tabular}

Jika dilihat dari syarat-syarat di atas, adanya program terkait konservasi dan pengelolaan sumber daya ikan yang dilakukan oleh masyarakat hampir selalu menjadi syarat, kecuali bagi unsur kelompok masyarakat dan masyarakat adat, unsur LSM provinsi atau kabupaten/kota, korporasi dan lembaga penelitian (dalam negeri dan asing).

Dengan demikian, bagi unsur masyarakat yang ingin berpartisipasi dalam program kemitraan KKP ini, penting untuk memastikan syarat formil - yang kerap terlupa karena kesibukan substantif - terpenuhi. Pengawasan terhadap ketaatan terhadap syarat substantif maupun formil dari masyarakat yang terlibat dalam program kemitraan ini juga penting untuk dilakukan, untuk mengantisipasi adanya oknum-oknum yang merekayasa kemitraan demi kepentingan pihak tertentu, misalnya seperti dikenal dengan LSM plat merah atau plat kuning. Bagi masyarakat yang melakukan inisiatif dengan mekanisme yang cair, dapat mempertimbangkan pelibatan sebagai unsur "masyarakat dan/atau masyarakat adat" dibandingkan membentuk LSM. Permen 21/2015 ini memberikan alternatif yang cukup fleksibel bagi para pihak untuk memilih kapasitasnya dalam kemitraan.

\section{Membangun Kapasitas Masyarakat}

Salah satu pemegang kepentingan dalam kemitraan KKP adalah masyarakat pesisir dan masyarakat adat. Kemitraan dalam Permen 21/2015 akan berinteraksi langsung dengan mereka, sehingga pendekatan mekanisme kerja dan kesepakatan dengan masyarakat juga memerlukan cara-cara yang sesuai dengan mekanisme, kapasitas dan keadaan sosiologis di lokasi tersebut. Terlepas dari perdebatan antropologis mengenai tepat tidaknya penggunaan pendekatan rigid-birokratis bagi masyarakat di tingkat akar rumput, hal ini 
menunjukkan pentingnya informasi mengenai kemitraan ini disampaikan dalam bentuk yang semudah-mudahnya dipahami masyarakat. Informasi tersebut perlu menjangkau serta mampu mengajak masyarakat untuk beradaptasi dengan prosedur yang ditetapkan. Jika memungkinkan, Pemerintah dapat melakukan inovasi-inovasi yang dapat mempermudah masyarakat dan meningkatkan kapasitasnya dalam perencanaan program, pemahaman hak dan kewajiban dalam perjanjian kemitraan, akuntabilitas, dsb.

Proses kemitraan KKP yang mencakup (1) Usulan Program Kemitraan, baik dari pemerintah maupun masyarakat; (2) Pembuatan dan penandatanganan Perjanjian Kemitraan; serta (3) Pembinaan, monitoring dan evaluasi mensyaratkan kapasitas manajerial dan kesekretariatan di level akar rumput. LSM dapat dan perlu berperan mendampingi masyarakat dalam hal-hal yang bersifat administratif ini. Kesadaran dan kehati-hatian dalam berkontrak juga perlu dipahami oleh masyarakat. Dengan mekanisme seperti ini, masyarakat perlu betul-betul memahami hak dan kewajiban dalam kemitraan, dan keadaankeadaan yang dapat menyebabkan salah satu pihak wanprestasi.

\section{Penutup}

Permen KP 21/2015 dapat bermanfaat sebagai peraturan yang dapat membawa dampak positif untuk memotivasi konservasi yang merangkul, bukan menyingkirkan masyarakat. Hal ini hanya dapat dicapai dengan syarat pelibatan masyarakat telah dilaksanakan sejak awal, bukan hanya di dalam pelaksanaan program. Perencanaan RPZ KKP perlu menyadari sepenuhnya isu-isu sebagaimana dipaparkan di bagian pertama tulisan ini. Selain itu, pemerintah perlu memetakan inisiatif-inisiatif baik di level akar rumput agar program-program dapat melibatkan aktor-aktor yang memang berkualitas, representatif dan dapat melakukan perubahan. Masyarakat sendiri perlu tetap mengawasi pelibatan yang mencurigakan dan menggunakan tekanan publik untuk mengarahkan pemerintah ke insiatif-inisiatif yang baik. Terakhir, masyarakat (khususnya masyarakat pesisir dan masyarakat adat) perlu mendapatkan informasi yang lebih memadai serta peningkatan kapasitas untuk menjembatani birokrasi program kemitraan ini dengan tetap mempertimbangkan situasi dan kondisi di akar rumput. 